\title{
THE IMPORTANCE OF GEOBACILLUS SPP. AS GROUP OF BACTERIAL CONTAMINATES IN THE DAIRY INDUSTRY
}

\author{
MARWA M.N. EL-GENDI and NAHED M. WAHBA \\ Animal Health Research Institute, Assiut Regional Laboratory. \\ Email: moazahmednofel@yaloo.com
}

\section{ABSTRACT}

Infant formulae are modern artificial substitutes for human breast milk. Formulas are designed for infant consumption, and are usually based on either cow milk or soy

Received at: 29/9/2013 milk. Geobacillus represents aerobic or facultative anaerobic, neutrophilic, obligatory thermophilic, endosporeforming bacteria. A total of ninety random samples of milk powder, Infant milk powder and milk-cereal based weaning food

Accepted: 26/10/2013 (30 samples each) were purchased from different shops and pharmacies in Assiut city. Samples were examined for total thermophillic count, total spore count at $37^{\circ} \mathrm{C}$ and $55^{\circ} \mathrm{C}$. The incidences of Geobacillus spp. and other bacillus spp. were also determined. The mean value of total thermophillic colony count/g was $10 \times 10^{3}$; $13 \times 10^{3}$ and $12 \times 10^{3} / \mathrm{g}$ of examined dried milk powder, infant milk formulae and milk-cereal based weaning food samples, respectively at $37^{\circ} \mathrm{C}$. While at $55^{\circ} \mathrm{C}$, it was $1 \times 10^{2}$ and $7.6 \times 10^{2} / \mathrm{g}$ in the same samples, respectively. Infant milk formulae were free. In addition, the mean of total spore count at 37 and $55^{\circ} \mathrm{C}$ were $22 \times 10^{2}$ and $10 \times 10^{3} / \mathrm{g}$ in milk powder samples, respectively and $11 \times 10^{3}$ and $59 \times 10^{2}$ in milkcereal based weaning food samples and $13 \times 10^{3}$ in infant milk formulae at $37{ }^{\circ} \mathrm{C}$. Geobacillus stearothermophilus could be isolated only from milk-cereal based weaning food in percentage of $16.7 \%$. Some other Bacillus spp. could be detected at different temperatures with different percentages. Lipolytic and proteolytic activities of G. stearothermophilus were also evaluated.

Key words: Geobacillus spp., dairy industry, milk

\section{INTRODUCTION}

Thermophilic bacilli, such as Anoxybacillus, Geobacillus and Bacillus are common contaminants growing within the processing lines of milk powder producing factories. Spores surviving processing (filling, temperature, sterilization of packaging material, etc.) can germinate, grow, and proliferate in the product (Scheldeman et al., 2006). Moreover, these contaminants are used as indicator organisms for plant hygiene and specification limits based on their numbers have been implemented to ensure milk powder quality.

Recently, Nazina et al. (2001) reclassified some existing Bacillus species within group $\mathrm{V}$ into the new genus Geobacillus based on phenotypic and genotypic characteristics. So far, the most recently published and recognized species are Geobacillus caldoxylosilyticus, $G$. debilis, $G$. gargensis, $G$. jurassicus, G. kaustophilus, G. lituanicus, G. pallidus, G. stearothermophilus, $G$. subterraneus, $G$. tepidamans, $G$. thermocatenulatus, $G$. thermodenitrificans, $G$. thermoglucosidasius, $G$. thermoleovorans, $G$. toebii, $G$. uzenensis and $G$. vulcani (Nazina et al., 2001, 2004; Banat et al., 2004; Schaffer et al., 2004; Zeigler et al., 2005).
G. stearothermophilus spores (formerly $B$. stearothermophilus) are extremely heat resistant, up to 20 times more resistant than Clostridium botulinum spores (Watanabe et al., 2003; Iciek et al., 2008). G. stearothermophilus spores typically survive canning and sterilization procedures of food products (Denny, 1981 and Brackett, 2001) and may cause spoilage problems especially where foods must be stored at elevated temperatures for a long time. Growth of $G$. stearothermophilus spores results in flat sour spoilage because acid is produced but with little or no gas generated (Brackett, 2001). Due to its heat resistance, this microorganism is often used as a biological indicator for testing the efficacy of sterilization processes (Chopra and Mathur, 1984 and Phillips and Griffiths, 1990). Furthermore, the capacity of this bacterium to adhere to stainless steel and grow in biofilms appears to be a likely cause of contamination of manufactured dairy products (Flint et al., 2001).

In the dairy industry, the thermophilic bacilli are usually enumerated using an aerobic plate count (APC) incubated at $55{ }^{\circ} \mathrm{C}$. Those that have been isolated from dairy products at this incubation temperature can be divided into two groups: the obligate thermophiles and the facultative thermophiles (also known as thermotolerant microorganisms). The obligate thermophiles grow 
only at elevated temperatures (approximately 40$68^{\circ} \mathrm{C}$ ) and include Anoxybacillus flavithermus and Geobacillus spp. (Flint et al., 2001; Ronimus et al., 2003; Scott et al., 2007). The facultative thermophiles belong to the Bacillus genus and tend to grow at both mesophilic and thermophilic temperatures, depending on the strain. Some examples of species include B. licheniformis, B. coagulans, B. pumilus, B. sporothermodurans and B. subtilis (Crielly et al., 1994; Flint et al., 2001; Ronimus et al., 2003, Scheldeman et al., 2005).

Feeherry et al. (1987) noted that many food products cannot withstand the heat treatment needed to inactivate thermophilic spores. Therefore, other measures such as the control of contamination of ingredients by thermophilic organisms, rapid cool below $4{ }^{\circ} \mathrm{C}$ after thermal processing, and controlled storage are required to prevent spoilage.

\section{MATERIALS and METHODS}

Collection, preparation and serial dilutions of samples:

A total of 90 random samples of milk powder, Infant milk powder and milk-cereal based weaning food (30 samples each) were purchased from different shops and pharmacies in Assiut city, Egypt. These samples were still valid for consumption as shelf life is at least to be more than one year from production time. Cartons and cans of samples were cleaned, thoroughly mixed and aseptically opened. Ten fold serial dilutions were carried out according to A.P.H.A. (1992).

Enumeration of total thermophiles:

$1 \mathrm{ml}$ of the sample and its decimal dilutions was plated using milk plate count agar (MPCA) and incubated at 37 and $55{ }^{\circ} \mathrm{C}$ for $48 \mathrm{~h}$ as described by Frank and Yousef (2004).

\section{Enumeration of total Spores:}

Firstly, the samples were heated at $80^{\circ} \mathrm{C}$ for $20 \mathrm{~min}$. to inactivate the vegetative cells and activate the spores, enabling them to germinate. The heat-treated sample is pour plated with MPCA supplemented with $0.2 \%$ starch and is incubated at $37^{\circ} \mathrm{C}$ and $55^{\circ} \mathrm{C}$ for 48 $\mathrm{h}$. The starch is added as an aid for spore germination (Murphy et al., 1999; McGuiggan et al., 2002 and Coorevits et al., 2008).

\section{Isolation of Geobacillus spp.:}

Tryptic soy agar with $0.2 \%$ soluble potato starch was chosen as the isolation medium and incubated at $37^{\circ} \mathrm{C}$ and $55^{\circ} \mathrm{C}$ for $48 \mathrm{~h}$ (Ronimus et al., 2003).

\section{Identification of isolates:}

Identification of bacterial isolates was performed based on their morphological, physiological, and biochemical characteristics, as described in Bergey's Manual of Systematic Bacteriology (Claus and Berkeley, 1986).

\section{Lipolytic and protylytic activity:}

To evaluate the proteolytic activity, the strains were plated on milk agar. The milk agar was prepared with plate count agar supplemented with $1 \%$ skimmed milk powder (Beerens and Luquet, 1990). The plates were incubated at $30^{\circ} \mathrm{C}$ for 48 hours. The positive results were indicated by transparent halo zone around the colonies.

For the evaluation of lipolytic activity, the strains were plated on tributyrin agar, prepared with plate count agar supplemented with $1 \%$ tributyrin (Beerens and Luquet, 1990). The plates were incubated at $30^{\circ} \mathrm{C}$ for 48 hours. The positive results were indicated by transparent halo zone around the colonies.

\section{RESULTS}

Table 1: Statistical analytical results of Total Thermophilic Count at $37^{\circ} \mathrm{C}$ and $55^{\circ} \mathrm{C}$.

\begin{tabular}{|c|c|c|c|c|c|c|c|c|c|c|c|}
\hline \multirow{3}{*}{$\begin{array}{c}\text { Examined } \\
\text { samples }\end{array}$} & \multirow{3}{*}{$\begin{array}{l}\text { No. of the } \\
\text { examined } \\
\text { samples }\end{array}$} & \multicolumn{5}{|c|}{ At $37^{\circ} \mathrm{C}$} & \multicolumn{5}{|c|}{ At $55^{\circ} \mathrm{C}$} \\
\hline & & \multicolumn{2}{|c|}{$\begin{array}{l}\text { Positive } \\
\text { samples }\end{array}$} & \multicolumn{3}{|c|}{ Count/g } & \multicolumn{2}{|c|}{$\begin{array}{l}\text { Positive } \\
\text { samples }\end{array}$} & \multicolumn{3}{|c|}{ Count $/ g$} \\
\hline & & No. & $\%$ & Min. & Max. & Mean & No. & $\%$ & Min. & Max. & $\begin{array}{c}\text { Mean } \pm \text { St } \\
\text { Error }\end{array}$ \\
\hline Milk powder & 30 & 21 & 70 & $1 \times 10^{2}$ & $38 \times 10^{3}$ & $10 \times 10^{3}$ & 2 & 6.7 & $1 \times 10^{2}$ & $1 \times 10^{2}$ & $1 \times 10^{2}$ \\
\hline $\begin{array}{l}\text { Infant milk } \\
\text { powder }\end{array}$ & 30 & 19 & 63.3 & $2 \times 10^{2}$ & $79 \times 10^{3}$ & $13 \times 10^{3}$ & $\mathbf{0}$ & 0 & 0 & 0 & 0 \\
\hline $\begin{array}{c}\text { Milk- cereal } \\
\text { based weaning } \\
\text { food }\end{array}$ & 30 & 25 & 83.3 & $4 \times 10^{3}$ & $33 \times 10^{3}$ & $12 \times 10^{3}$ & 13 & 43.3 & $2 \times 10^{2}$ & $1 \times 10^{3}$ & $7.6 \times 10^{2}$ \\
\hline
\end{tabular}


Table 2: Statistical analytical results of Total Spore Count at $37^{\circ} \mathrm{C}$ and $55^{\circ} \mathrm{C}$.

\begin{tabular}{|c|c|c|c|c|c|c|c|c|c|c|c|}
\hline \multirow{3}{*}{$\begin{array}{c}\text { Examined } \\
\text { samples }\end{array}$} & \multirow{3}{*}{$\begin{array}{l}\text { No. of the } \\
\text { examined } \\
\text { samples }\end{array}$} & \multicolumn{5}{|c|}{ At $37^{\circ} \mathrm{C}$} & \multicolumn{5}{|c|}{ At $55^{\circ} \mathrm{C}$} \\
\hline & & \multicolumn{2}{|c|}{$\begin{array}{l}\text { Positive } \\
\text { samples }\end{array}$} & \multicolumn{3}{|c|}{ Count/g } & \multicolumn{2}{|c|}{$\begin{array}{l}\text { Positive } \\
\text { samples }\end{array}$} & \multicolumn{3}{|c|}{ Count /g } \\
\hline & & No. & $\%$ & Min. & Max. & Mean & No. & $\%$ & Min. & Max. & Mean \\
\hline $\begin{array}{c}\text { Milk } \\
\text { powder }\end{array}$ & 30 & 25 & 83.3 & $1 \times 10^{2}$ & $15 \times 10^{3}$ & $22 \times 10^{2}$ & 4 & 13.3 & $1 \times 10^{2}$ & $38 \times 10^{3}$ & $10 \times 10^{3}$ \\
\hline $\begin{array}{c}\text { Infant milk } \\
\text { powder }\end{array}$ & 30 & 10 & 33.3 & 20 & $44 \times 10^{3}$ & $13 \times 10^{3}$ & 0 & 0 & 0 & 0 & 0 \\
\hline $\begin{array}{c}\text { Milk- cereal } \\
\text { based } \\
\text { weaning } \\
\text { food }\end{array}$ & 30 & 18 & 60 & $1 \times 10^{3}$ & $81 \times 10^{3}$ & $11 \times 10^{3}$ & 13 & 43.3 & $1 \times 10^{3}$ & $19 \times 10^{3}$ & $59 \times 10^{2}$ \\
\hline
\end{tabular}

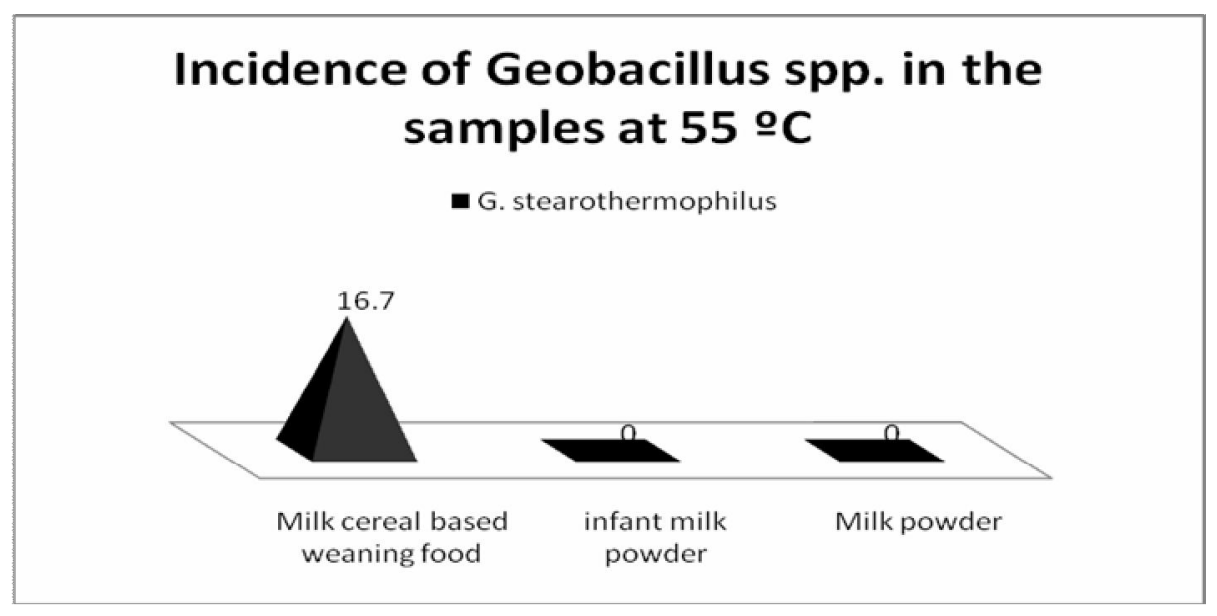

Figure 1: Incidence of Geobacillus spp. in the examined samples at $55^{\circ} \mathrm{C}$.

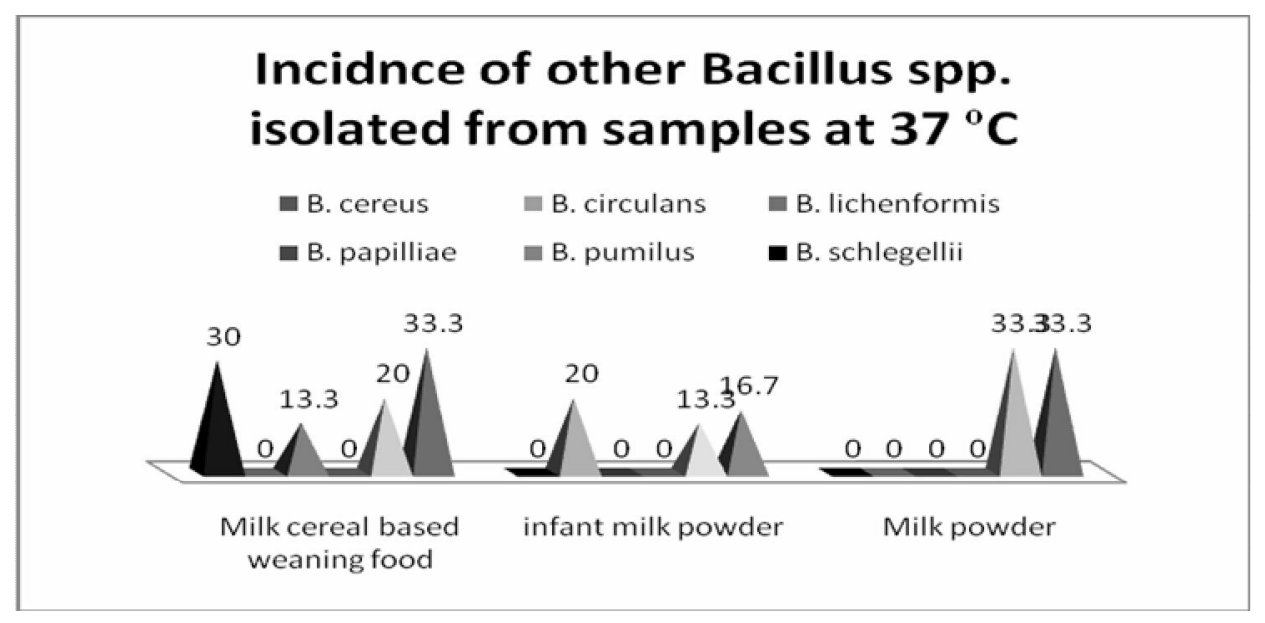

Figure 2: Incidence of other Bacillus spp. in the examined samples at $37^{\circ} \mathrm{C}$. 


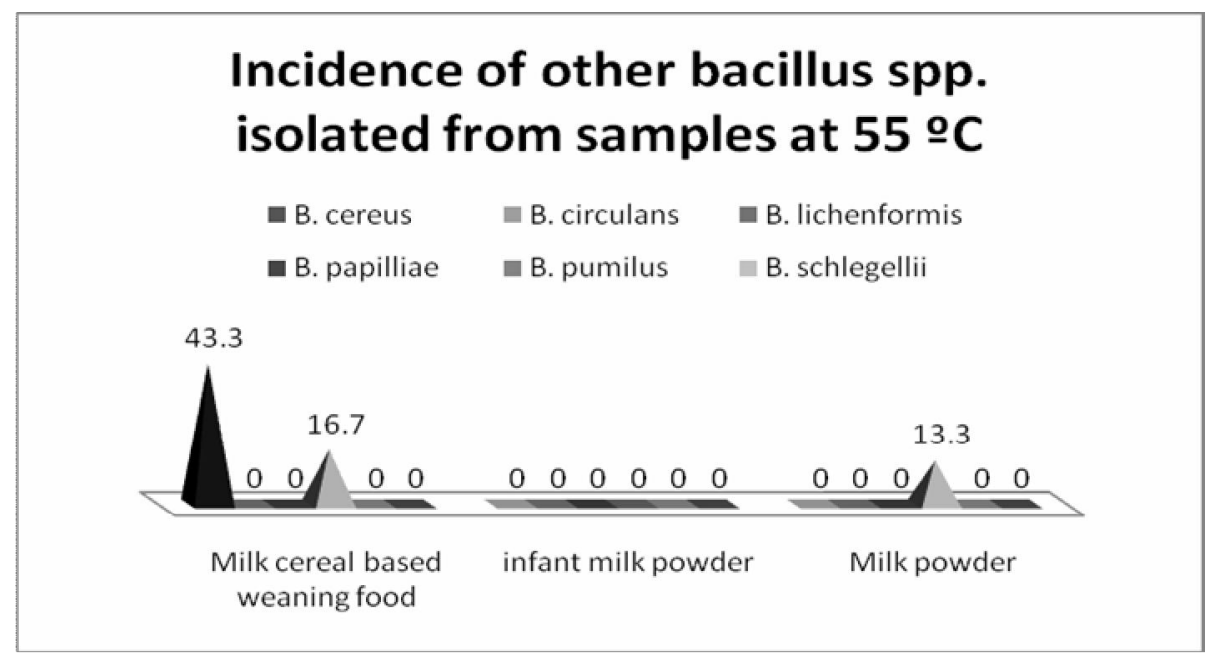

Figure 3: Incidence of other Bacillus spp. in the examined samples at $55^{\circ} \mathrm{C}$.

\section{DISCUSSION}

Although it is universally accepted that these thermophilic bacilli do not constitute a health risk to the consumer, they have been deemed to be an indicator of plant hygiene during processing, and specification limits have been implemented based on numbers of thermophilic bacilli in products (Murphy et al., 1999; Kwee et al., 1986; Ronimus et al., 2003). Recently, the thermophilic bacilli could not only cause spoilage due to their production of acids and thermostable enzyme excretion, but also cause foodborne illness (Burgess et al., 2010).

In the present study, the mean count of total thermophillic count at $37^{\circ} \mathrm{C}$ in the examined samples were $10 \times 10^{3}, 13 \times 10^{3}$ and $12 \times 10^{3} / \mathrm{g}$ and found to be $1 \times 10^{2}, 0$ and $7.6 \times 10^{2} / \mathrm{g}$ at $55^{\circ} \mathrm{C}$ in examined samples of milk powder, infant milk formulae and milk-cereal based weaning food samples, respectively (Table 1). The percentage of total thermophilic counts at $37^{\circ} \mathrm{C}$ were $70,63.3$ and $83.3 \%$, while at $55^{\circ} \mathrm{C}$ were $6.7,0$ and 43.3in the examined samples respectively. Dong et al. (2012) could isolate $B$. licheniformis in percent of $27.8 \%$ in the examined samples of milk powder and it considered higher than that obtained in this study. Thermophilic bacilli had been isolated from milk powder plants in New Zealand and also from milk powders collected from 18 countries around the world, and the dominant thermophilic bacilli in milk powder samples were relatively consistent (Ronimus et al., 2003; Rueckert et al., 2004; Scott et al., 2007).

From Table (2), total spore count were detected in $83.3,33.3$ and $60 \%$ in examined samples of milk powder, infant milk formulae and milk-cereal based weaning food samples, respectively at $37^{\circ} \mathrm{C}$. At $55^{\circ} \mathrm{C}$, total spore count failed to be detected in the examined samples of infant milk formulae, while the mean total spore count reached to $10 \times 10^{3}$ and $59 \times 10^{2} / \mathrm{g}$ in the examined samples of milk powder and milk-cereal based weaning food, respectively.

Spores are resistant to heat, mechanical disruption and a wide variety of chemicals, making it very hard to destroy them in dairy manufacturing processes (Jones et al., 2005 and Scheldeman et al., 2006).

Typically, milk powder is produced continuously over an 18-24 $\mathrm{h}$ processing period during which the number of thermophilic bacilli in the product often mirrors that of a typical bacterial growth curve. Thus, with increased processing time, the number of thermophiles increases until specification limits are reached and the process run is terminated to prevent product downgrading. Many factors, such as the microbiological quality of the raw milk or the thermal operating conditions in the plant (low-, medium or high heat treatments) or the plant hygiene can all affect the growth of thermophiles in the processing line, making it difficult to predict a processing time that ensures thermophile numbers at the end of the run are below specified limits. In practice, actual numbers of contaminants in milk powders are determined retrospectively by plate counting, providing results commonly after $16-48 \mathrm{~h}$. Due to these microbiological constraints, it is common practice to terminate processing runs by initiating CIP (cleaning in place) with the expectation that the numbers of thermophilic bacilli will be below their specification limits (Stadhouders et al., 1982; Murphy et al., 1999; Kwee et al., 1986; Ronimus et al., 2003).

It's of interesting observation, that $G$. stearothermophilus could be isolated only from milkcereal based weaning food in percentage of $16.7 \%$ ( 5 samples) and failed to be detected in other examined samples (Fig.1). Dong et al. (2012) could isolate $G$. stearothermophilus in higher percentage from milk powder (12.4\%) Geobacillus strains have been isolated from temperate areas, as well as hot 
environments, such as hot springs, oilfields, deep sea sediments, sugar refineries and dairy factories (Tai et al., 2004).

Other Bacillus spp., could be found in the examined samples of milk powder where B. cereus and $B$. circulans in percentage of 33.3 and $33.3 \%$ at $37^{\circ} \mathrm{C}$, respectively. While, B. lichenformis could be isolated in percentage of $13.3 \%$ at $55{ }^{\circ} \mathrm{C}$. At $37^{\circ} \mathrm{C}$, $B$. cereus, B. circulans and B. pumilus could be identified in 16.7, 13.3 and $20 \%$ of isolates of infant milk formulae, respectively. Milk-cereal based weaning food samples found to be contaminated with $B$. cereus, B. circulans, B. papilliae and B. schlegellii at $37{ }^{\circ} \mathrm{C}$ and contaminated with $B$. lichenformis and B. schlegellii in percentage of 16.7 and $43.3 \%$, respectively at $55^{\circ} \mathrm{C}$ (Figures 2 and 3).

Another study in New Zealand milk powder plants revealed that seven strains of thermophilic bacilli were able to grow at $55{ }^{\circ} \mathrm{C}$ or above and recognized as the major contaminants growing in the processing lines (Ronimus et al., 2003). These are $G$. stearothermophilus, Anoxybacillus flavithermus, $B$. licheniformis and B. subtilis. Furthermore, a second investigation on milk powders from 18 different countries demonstrated that A. flavithermus. $B$. Licheniformis and $G$. stearothermophilus represent world-wide sources of contamination being nearubiquitously present in milk powders, and are thus of economic importance in processing (Rueckert et al., 2004).

Strains of obligate and facultative thermophiles are capable of producing acids, as well as a variety of heat-stable enzymes, including proteinases and lipases, which could result in the spoilage of dairy products (Gundogan and Arik, 2004; Murugan and Villi, 2009). In the present study, all $G$. stearothermophilus isolates have lipolytic and proteolytic activities. The real potential for the obligate thermophiles to spoil dairy products is thought to be low, as dairy products are generally stored at temperatures below $37{ }^{\circ} \mathrm{C}$, temperatures at which obligate thermophiles will not grow. However, G. stearothermophilus has been associated with 'flatsour' spoilage in a variety of canned food products, including evaporated milk (Kalogridou-Vassiliadou, 1992). In the case of facultative thermophiles, some strains of $B$. licheniformis are also capable of producing a slimy extracellular substance that can affect the quality of pasteurised milk and cream (Gilmour and Rowe, 1990).

In fact, the levels of thermophiles in raw milk are usually very low (e.g. b10 cfu/mL) (Hill and Smythe, 1994; McGuiggan et al., 2002). On rare occasions when higher levels do occur (e.g. N100 cfu/mL), the predominant thermophilic species in this raw milk tend to be $B$. licheniformis and $B$. coagulans. However, when the final product from raw milk of this quality is processed, the predominant thermophilic species tend to be $A$. flavithermus and Geobacillus spp (Burgess et al., 2010).

\section{CONCLUSION}

These contaminants are used as indicator organisms for plant hygiene and specification limits based on their numbers have been implemented to ensure milk powder quality. The attention of industry and researcher should be focused on dairy products stored at room temperature, since the occurrence of strains producers of proteases was highest at $30^{\circ} \mathrm{C}$. Taking into account that these products have a long shelf life, these enzymes may act on proteins, altering their sensory characteristics. Consumers' demands increasingly aim at high-quality, minimally processed, nutritious and fresh-like products. Traditional thermal processing methods cause loss of desirable properties related to texture, flavor, color, and nutrient value. However, the most serious commercial problems with product sterility are caused by thermally resistant spores. In an attempt to provide alternatives to solve these problems,

\section{REFERENCES}

A.P.H.A. (1992): Standard Methods for the Examination of Dairy Products. 13th Ed., American Public Health Association.

Banat, I.M.; Marchant, R. and Rahman, T.J. (2004): Geobacillus debilis sp. nov., a novel obligately thermophilic bacterium isolated from a cool soil environment, and reassignment of Bacillus pallidus to Geobacillus pallidus comb. nov. Int. J. Syst. Evol. Microbiol., 54: 2197- 2201.

Beerens, H. and Luquet, F.M. (1990): Practical guide for microbiological analysis of milk and dairy products. Zaragoza: Editorial Acríbia S.A.

Brackett, R.E. (2001): Fruits, vegetables, and grains. In: Doyle, M., Beuchat, L.R., Montville, T.J. (Eds.), Food Microbiology, Fundamentals and Frontiers, second ed. ASM Press, Washington, D.C, pp. 127-138.

Burgess, S.A.; Lindsay, D. and Flint, S.H. (2010): Thermophilic bacilli and their importance in dairy processing. Inter. J. Food Microbiol., 144: 215-225.

Chopra, A.K. and Mathur, D.K. (1984): Isolation, screening and characterization of thermophilic Bacillus species isolated from dairy products. The J. App. Bacteriol., 57: 263-271.

Claus, D. and Berkeley, R.C.W. (1986): Genus Bacillus. In Bergey's Manual of Systematic Bacteriology, pp. 1105-1139, Williams \& Wilkins, Baltimore.

Coorevits, A.; De Jonghe, V.; Vandroemme, J.; Reekemans, R.; Heyrman, J.; Messens, W.; De Vos, P. and Heyndrickx, M. (2008): 
Comparative analysis of the diversity of aerobic spore-forming bacteria in raw milk from organic and conventional dairy farms. Syst. and Appl. Microbiol., 31: 126-140.

Crielly, E.M.; Logan, N.A. and Anderton, A. (1994): Studies on the Bacillus flora of milk and milk products. J. Appl. Bacteriol., 77: 256-263.

Denny, C.B. (1981): Thermophilic organisms involved in food spoilage: introduction. J. Food Prot., 44: 144-145.

Dong, Y.; Guan-Chen, L.; Dong-Yan, R.; Dong, Z.; Lu, Z.; Chuan-Pu, K.; Yu-Zheng, Y.; Wei, M.; Yan, L. and Lie-Bing Z. (2012): A survey on occurrence of thermophilic bacilli in commercial milk powders. Food Control, 25: $752 \mathrm{e} 757$

Feeherry, F.E.; Munsey, D.T. and Rowley, D.B. (1987): Thermal inactivation and injury of Bacillus stearothermophilus spores. Appl. Environ. Microbiol. 53: 365-370.

Flint, S.; Palmer, J.; Bloemen, K.; Brooks, J. and Crawford, R. (2001): The growth of Bacillus stearothermophilus on stainless steel. J. Appl. Microbiol., 90: 151-157.

Frank, J.F. and Yousef, A.E. (2004): Thermophilic bacteria. In: Wehr, M.H., Frank, J.F. (Eds.), Standard Methods for the Examination of Dairy Products. American Public Health Association, Washington, DC, pp. 230-231.

Gilmour, A. and Rowe, M.T. (1990): Microorganisms associated with milk. In: Robinson, R.K. (Ed.), Dairy Microbiology. Elsevier Applied Science, London, pp. 37-76.

Gundogan, N. and Arik, M.T. (2004): Comparison of the protease activity of psychrotrophic and thermophilic Bacillus spp. isolated from raw milk samples. The Indian Vet. J., 81: 1013-1015.

Hill, B.M. and Smythe, B.W. (1994): Progress in Understanding the Behaviour of Thermophilic Bacteria During Milk Powder Manufacture. Milk Powders for the Future II. The Dunmore Press Limited, Palmerston North, In. pp. 19-26.

Iciek, J.; Blaszczyk, I. and Papiewska, A. (2008): The effect of organic acid type on thermal inactivation of Geobacillus stearothermophilus spores. J. Food Eng. 87: 16-20.

Jones, C.A.; Padula, N.L. and Setlow, P. (2005): Effect of mechanical abrasion on the viability, disruption and germination of spores of Bacillus subtilis. J. App. Microbiol., 99, 1484-1494.

Kalogridou-Vassiliadou, D. (1992): Biochemical activities of Bacillus species isolated from flat sour evaporated milk. J Dairy Sci., 75: 2681-2686.

Kwee, W.S.; Dommett, T.W.; Giles, J.E.; Roberts, R.; Smith, R.A.D.; Lin, C.C.; Wu, B.K. and Lin, D.K. (1986): Spoilage bacteria in canned foods. I. Flat sour spoilage bacteria in canned asparagus and the thermal death time. Appl. Environ. Microbiol., 16: 45-47.

McGuiggan, J.T.M.; McCleery, D.R.; Hannan, A. and Gilmour, A. (2002): Aerobic spore-forming bacteria in bulk raw milk: factors influencing the numbers of psychrotrophic, mesophilic and thermophilic Bacillus spores. Inter. J. Dairy Technol., 55: 100-107.

Murphy, P.; Lynch, D. and Kelly, P. (1999): Growth of thermophilic spore forming bacilli in milk during the manufacture of low heat powders. Inter J. Dairy Technol., 52: 45-50.

Murugan, B. and Villi, R.A. (2009): Lipolytic activity of Bacillus species isolated from milk and dairy products. The Indian Vet. J., 86: 80-81.

Nazina, T.N.; Lebedeva, E.V.; Poltaraus, A.B.; Tourova, T.P.; Grigoryan, A.A.; Sokolova, D.S.; Lysenko, A.M. and Osipov, A.G. (2004): Geobacillus gargensis sp. nov., a novel thermophile from a hot spring, and the reclassification of Bacillus vulcani as Geobacillus vulcani comb. nov, Int. J. Syst. Evol. Microbiol., 54: 2019-2024.

Nazina, T.N.; Tourova, T.P.; Poltaraus, A.B.; Novikova, E.V.; Grigoryan, A.A.; Ivanova, A.E.; Lysenko, A.M.; Petrunyaka, V.V.; Osipov, G.A. and Belyaev, S.S. (2001): Taxonomic study of aerobic thermophilic bacilli: description of Geobacillus subteaneus gen. nov., sp. nov. and Geobacillus uzenensis sp. nov. from petroleum reservoirs and transfer of Bacillus stearothermophilus, Bacillus thermocatenulatus. Int. J. Syst. Evol. Microbiol., 51, 433-446.

Phillips, J.D. and Griffiths, M.W. (1990): Pasteurised dairy products: the constraints imposed by environmental contamination. In: Nriagu, J.O., Simmons, M.S. (Eds.), Food Contamination from Environmental Sources. Wiley, USA, pp. 387-456.

Ronimus, R.S.; Parker, L.E.; Turner, N.; Poudel, S.; Rückert, A. and Morgan, H. (2003): A RAPDbased comparison of thermophilic bacilli from milk powders. Inter. J. Food Microbiol., 2644: $1-17$.

Rueckert, A.; Ronimus, R.S. and Morgan, H.W. (2004): A RAPD-based survey of thermophilic bacilli in milk powders from different countries. Inter. J. Food Microbiol., 96: 263272.

Schaffer, C.; Franck, W.L.; Scheberl, A.; Kosma, P.; McDermott, T.P. and Messner, P. (2004): Classification of isolates from locations in Austria and Yellowstone National Park as Geobacillus tepidamans sp. nov. Inter. J. Syst. Evol. Microbiol., 54: 2361-2368.

Scheldeman, P.; Herman, L.; Foster, S. and Heyndrickx, M. (2006): Bacillus sporothermodurans and other highly heat- 
resistant spore formers in milk. J. Appl. Microbiol., 101: 542-555.

Schelderman, P.; Pil, A.; Herman, L.; De Vos, P. and Heyndrickx, M. (2005): Incidence and diversity of potentially highly heat-resistant spores isolated at dairy farms. App. Environ. Microbiol., 71: 1480 -1494.

Scott, S.A.; Brooks, J.D.; Rakonjac, J.; Walker, K.M.R. and Flint, S.H. (2007): The formation of thermophilic spores during the manufacture of whole milk powder. Inter. J. Dairy Technol., 60: 109-117.

Stadhouders, J.; Hup, G. and Hassing, F. (1982): The conceptions index and indicator organisms discussed on the basis of the bacteriology of spray-dried milk powder. Netherlands Milk and Dairy J., 36: 231-260.
Tai, S.K.; Lin, H.P.P.; Kuo, J. and Liu, J.K. (2004): Isolation and characterization of a cellulolytic Geobacillus thermoleovorans T4 strain from sugar refinery wastewater. Extremophiles 8, 345-349.

Watanabe, T.; Furukawa, S.; Hirata, J.; Koyama, T.; Ogihara, H. and Yamasaki, M. (2003): Inactivation of Geobacillus stearothermophilus spores by high-pressure carbon dioxide treatment. Appl. Environ. Microbiol., 69: 7124-7129.

Zeigler, D.R. (2005): Application of a recN sequence similarity analysis to the identification of species within the bacterial genus Geobacillus. Inter. J. Syst Evol Microbiol., 55: 1171-1179.

\section{أهمية أجناس الجيوباسيلس كمجموعة من الملوثات البكتيرية في صناعة الألبان \\ مروة محمد نبيل الجندي ، ناهد محمد وهبة \\ Email: moazahmednofel@yaloo.com}

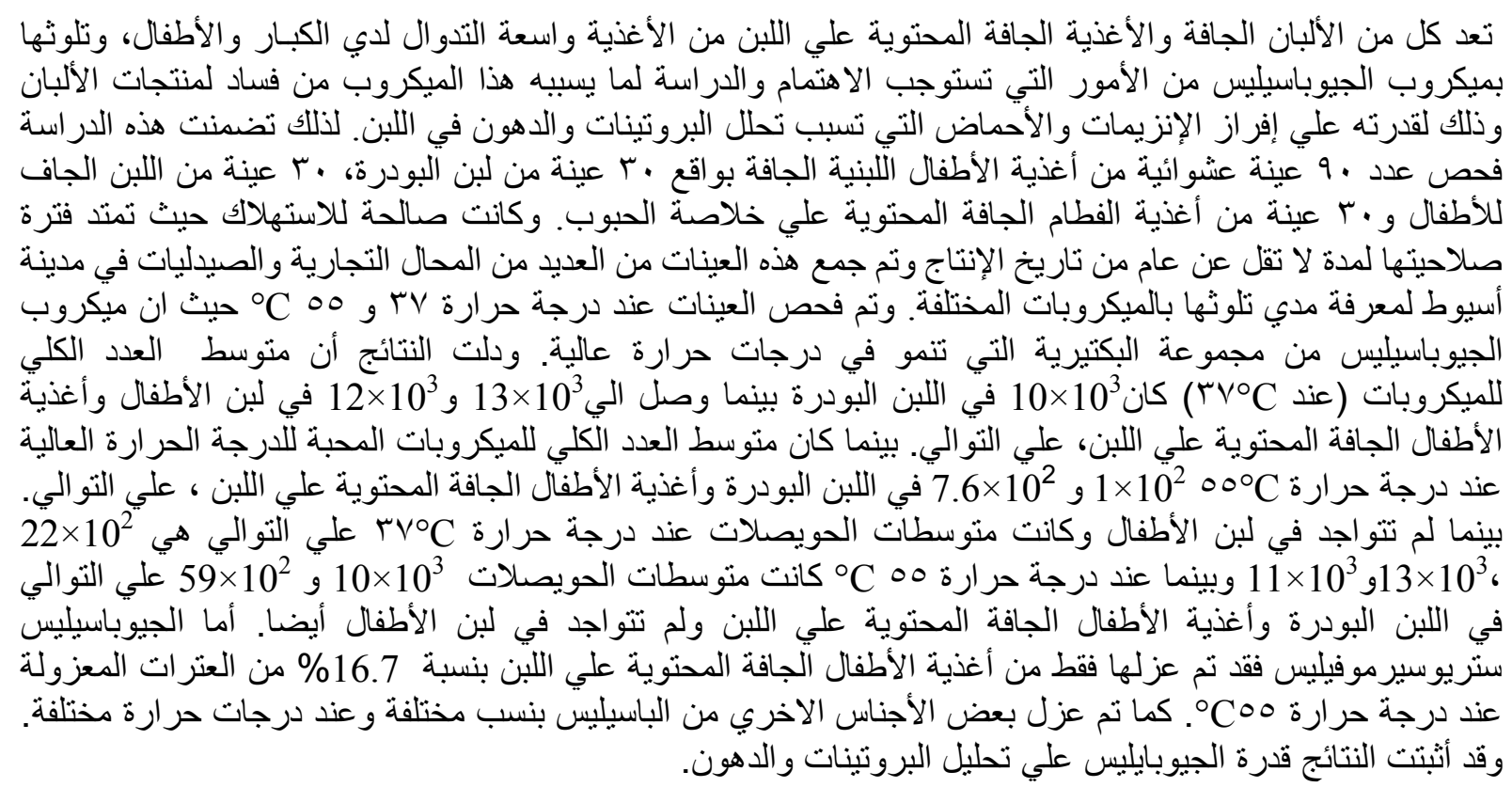

